\title{
Moderating Role of Corruption Control on Firm Level Determinants of Corporate Sustainability Disclosure Compliance in Nigeria
}

\author{
MOHAMMED SABO BELLO ${ }^{1}$, RIDZWANA MOHD SAID², JALILA JOHARI ${ }^{3}$, \\ FAKARUDIN KAMARUDIN ${ }^{4}$ \\ ${ }^{1}$ Department of Accountancy, YOBE STATE UNIVERSITY, NIGERIA. E-mail: msabobello@yahoo.com \\ 1,2,3,4 School of Business and Economics, UNIVERSITI PUTRA MALAYSIA, MALAYSIA.
}

\begin{abstract}
This paper explores the moderating effect of corruption control in strengthening the influence of firm attributes on corporate sustainability disclosure compliance in Nigeria. The study focuses on the existing discussion on mandatory disclosure compliance with a corporate governance code. The extent of disclosure compliance is measured using a total unweighted disclosure index, developed from a panel data set of 118 companies listed on the Nigerian capital market. The companies were selected using a proportionate stratified sampling technique. The dataset for the period of 2011 to 2017 were first analyzed by static panel regression analysis. The regression models were subjected to further robustness checks under dynamic GMM panel regression analysis, to test for possible endogeneity. The findings revealed the significant moderating effect of corruption control, evidenced from the interaction of corruption control with selected firm attributes, namely; industry type, leverage and taxation. The research contributes to the existing literature, as it establishes the importance of control of corruption as an additional factor of corporate sustainability disclosure compliance within the context of Nigeria.
\end{abstract}

Keywords: Environmental and Social Information; Corporate Governance; Compliance; Corruption Control JEL Classification: G3, M4, Q56 


\section{Introduction}

Corruption has been considered as a global issue over the last three decades (UN, 2017b). It is also considered to be a challenge to achieve the sustainable development goals (SDG) of ending extreme poverty by the year 2030 (World Bank, 2018). Corrupt practices constitute a critical setback in the growth of businesses operating in developing economies (Issa \& Alleyne, 2018). In order to combat corruption, with the aim of developing a strong anti-corruption policies, it is necessary to understand the different ways in which it manifests. Currently, the recognized bodies established in Nigeria to fight corruption are: the Independent Corrupt Practices Commission (ICPC), established in the year 2000 with the aim of eradicating corruption in the public service; and, the Economic and Financial Crime Commission (EFCC), which was created in 2003 as a result of pressure by the financial action task force on money laundering. The operations of the aforementioned institutions are interconnected with the judicial system, and any accused cases of corruption are tried in the court law.

Within the preface of the 2003 corporate governance (CG) code issued by the Nigeria Securities and Exchange Commission, which was followed by the 2011 mandatory CG code. The 2011 code was further replaced by the 2016 CG code, and this current code is considered to be the unified code of corporate governance. The cardinal objective of the code among others, is to encourage sustainability disclosure among the listed companies in Nigeria. However, Onyali, Okafor, \& Egolum (2014) reveal that the level of social and environmental disclosure level in Nigeria is very short and simply descriptive. Despite the existence of the code, some literature has documented that some companies are enthusiastic about reporting good news, to reduce the effect of negative reporting (latridis, 2013).

Moreover, evidence from the transparency international corruption index, reports that Nigeria is ranked $146^{\text {th }}$ out of 180 countries assessed, where the $180^{\text {th }}$ country is ranked worst for corruption control (Trading Economics, 2020). The Business Anti-Corruption Portal (2018) report shows that the issue of corruption is still Nigeria's greatest obstacle to business, and that companies in Nigeria are likely to engage in bribery and corrupt practices. However, much corruption may be prevented by strong institutions; especially with cooperation from the private sector in ceasing to issue bribes (World Bank, 2018). The current fight against corruption in Nigeria has also not yielded meaningful results, due to lack of complementary support from the judiciary (Salihu \& Gholami, 2019). Moreover, the extent to which the level of corruption control influences corporate sustainability disclosure compliance (CSDC) with the Nigerian CG code is yet to be ascertained by researchers. Thus, this paper aims to examine the moderating effect of corruption control in strengthening the relationship between firm attributes and CSDC in Nigeria.

\section{Literature Review}

Prior literature has established empirical evidence on the role of corruption control upon various constructs. Some researchers have considered the issue of anti-corruption within the context of corporate disclosure. For example, Issa \& Alleyne (2018) examined corporate reports from the Gulf countries, with the aim of elaborating the extent of anti-corruption information in the annual reports. The results of content analysis of 2014 sustainability reports provided detailed information that code of conduct compliance disclosure was related to anti-corruption practices by GCC firms. Similarly, Lasagni, Nifo, \& Vecchione (2015) explored the role that institution quality played in the productivity of 4000 private companies in Italy, between 1998 and 2007. The findings provided evidence on the link between institutional qualities and firm productivity.

Furthermore, Healy \& Serafeim (2015) investigated whether disclosure made by 408 firms reflected actual effort in the fight against corruption, or otherwise. Using an anti-corruption report of Transparency International scoring index, the findings revealed that strong enforcement parameters, such as laws and regulations, industry corruption risk, use of big 4 auditors, and board independence, all predictably influenced the extent of anti-corruption reporting made by firms. Similarly, Branco \& Matos (2016) analyzed statements made by firms related to the fight against corruption, as reported in sustainability reports of some selected firms in Portugal. Findings from the study revealed that 
companies with high visibility to the risk of corruption, disclosed more information to protect their corporate image.

Shan, Lin, Li, \& Zeng (2018) used a panel regression analysis of 22 countries in the African continent between 2008 and 2018, and found that voice, and sound corporate accountability significantly influence Chinese Foreign Direct Investment (FDI) attraction to Africa. . Furthermore, considering the role of institutions in economic growth and firm development. Krasniqi \& Mustafa (2016) used a questionnaire survey of 1,606 of Kosovar entrepreneurs, which empirically showed corruption to be an institutional quality variable that had significant influence on firm growth. More specifically, institutional quality affects the maturity of long-term debt, as was made evident by Tresierra \& Reyes (2018) in a study of companies in both Peru and Brazil, which aimed at determining the extent to which national institutions condition the time horizon of debt maturity.

Therefore, it is evident that, prior research has investigated the concept of corruption, linking it with concepts ranging from anti-corruption disclosure, environmental regulations, and economic growth among others. However, researchers give less attention to the moderating effect of corruption control in exploring the firm attributes that influence CSDC. The study contributes empirically by investigating the extent to which corruption controlling moderate the influence of firm attributes on corporate sustainability disclosure compliance.

\subsection{The Theory}

The theory of new institutionalism (neo-institutional theory) is now widely accepted, the theory has been developed with a focus on deeper, and more resilient aspects of social structure. The theory considers the processes by which structures, including schemes, rules, norms, and routines, become established as authoritative guidelines for social behavior. The theory also integrates policy making, with emphasis on legal and formal aspects of government structures (Powell, 1988). Institutional theory, literature has long posited that corporations are segments of a wider social structure, which comprises of both formal (e.g., government regulations and laws) and informal (e.g., cultural norms and practices) institutions, and which significantly shape corporate behaviour to further impact organisational outcome (Campbell, 2007).

DiMaggio \& Powell (1991) outlined three mechanisms of institutional isomorphism, namely; normative, mimetic and coercive. Normative isomorphism emphasises individuals as units of analysis, while the mimetic and coercive mechanisms consider the organisation as a unit of analysis (Mohd Said, Sulaiman, \& Ahmad, 2014). The current study focuses on the coercive isomorphism institutionalism, and aims to contribute to theory through investigation of the moderating effect of corruption control through the establishment of firm level determinants supporting CSDC with the Nigerian corporate governance code. The concept of coercive isomorphism has been applied in a wide range of prior (Eltaib \& Complete, 2012; Joseph et al., 2016; Mohd Said et al., 2014). The fact that organisations are viewed as an integrated part of larger institutional environment, may alter their reporting behaviour, as influenced by shared belief and practice in a particular system (Atwood, et al., 2012). Moreover, a higher level of trust in government, leads to increased level of compliance to rules and regulations. These factors together motivate firms to behave in a more sensible, socially and environmentally responsible manner.

\subsection{Hypothesis Development}

The current study asserted that the economic situation of a country can have significant influence on the amount of information that firm disclosure over a given period of time, and to a larger extent can affect the level of compliance to regulations. Based on the new Institutional theory, legislated environmental laws depend on the sector in which a company operates, and hence there may be variations in enforcement policy (Acemoglu, Johnson, Robinson, \& Thaicharoen, 2003). Institutionally weak systems, with low level of trust, lead to poor compliance with rules, regulations and codes. Corruption is considered to be one of the major factors in deteriorating institutional quality of a 
country, and is also reported to have a significant negative relationship with a wide range of factors impacting small business growth (Krasniqi \& Mustafa, 2016). In addition, prior studies further provide evidence on the relationship of corruption control on corporate disclosure, environmental regulations and economic development (Branco \& Matos, 2016; Healy \& Serafeim, 2015; Issa \& Alleyne, 2018; Lasagni et al., 2015; Shan et al., 2018; Tresierra \& Reyes, 2018). Thus, the current study aims to test the moderating effect of corruption control in the context of CSDC, using the following hypothesis;

$\mathrm{H}_{a}$ : The influence of firm attributes on CSDC is strengthen with corruption control.

\section{Methodology}

\subsection{Sample and Data Source}

The sample size consisted of 118 listed companies in Nigeria were selected across a range of different industries, out of 170 companies (SEC, 2018, ) Qureshi, M. I., Khan, N., Qayyum, S., Malik, S., Sanil, H. S., \& Ramayah, T. 2020). Selection of the sample was based on Krejcie and Morgan (1970). The firm level data points for the current study were extracted from sampled company annual reports, for a period of seven years (2011 to 2017), while country level data on corruption control was obtained from The Global Economy official website. The current study used a stratified random sampling technique, which involved segregation and stratification of subjects within a population into mutually exclusive groups, followed by random selection of elements from each of the strata (Sekaran, 2003). Table 1, below, displays the sample distribution across industries in Nigeria.

Table 1: Sampling Distribution

\begin{tabular}{|c|c|c|}
\hline Industry & Number of Elements & Proportionate Sample Size \\
\hline Agriculture & 5 & 3 \\
\hline Conglomerate & 6 & 4 \\
\hline Construction/Real estate & 9 & 6 \\
\hline Consumer goods & 21 & 15 \\
\hline Financial services & 57 & 40 \\
\hline Health services & 10 & 7 \\
\hline ICT & 7 & 5 \\
\hline Industrial goods & 14 & 3 \\
\hline Natural resources & 4 & 8 \\
\hline Oil and gas & 12 & 17 \\
\hline Services & 25 & 118 \\
\hline Total & 170 & 10 \\
\hline
\end{tabular}

\subsection{Model Specification under Static Regression Analysis}

The models of the study were designed to explore the moderating effects of corruption control on the relationship between firm attributes and corporate sustainability disclosure compliance. All models were subjected to a series of diagnostic tests, specifically; the test for multicollinearity using a correlation matrix and variance inflation factor (vif), the test for heteroscedasticity using modified Wald statistical diagnostics, the Wooldridge test for autocorrelation in panel data, and Cook's distance test for outliers. STATA 14 software is used for the data analysis. Moreover, the research models provided include testing the direct relation in model S1, and subsequent test for the moderating effects of corruption control through the introduction of the variable $\mathrm{X}_{12}$, signifying the interaction between each firm attributes and the moderating variable (Iccon), in each of models S2 to S5.

$$
\text { Icsdc }_{i t}=\alpha_{0}+\beta_{1} \text { lliqd }_{\text {it }}+\beta_{2} \text { indt }_{\text {it }}+\beta_{3} \text { lleve }_{\text {it }}+\beta_{4} \text { Itaxa }_{\text {it }}+\beta_{5} \text { Ifsize }_{\text {it }}+\beta_{6} \text { Ifage }_{i t}+\beta_{7} \text { Iccon }_{t}+\lambda_{i}+\varepsilon_{i t}
$$




$$
\begin{aligned}
& \text { Icsdc }_{\text {it }}=\alpha_{0}+\beta_{1} \text { lliqd }_{\text {it }}+\beta_{2} \text { indt }_{\text {it }}+\beta_{3} \text { lleve }_{\text {it }}+\beta_{4} \text { Itaxa }_{\text {it }}+\beta_{5} \text { Ifsize }_{\text {it }}+\beta_{6} \text { Ifage }_{\text {it }}+\beta_{7} \text { Iccon }_{t}+ \\
& \beta_{8}\left(\operatorname{lliqd}_{i t} \times \operatorname{lccon}_{\mathrm{t}}\right)+\lambda_{\mathrm{i}}+\varepsilon_{\mathrm{it}} \cdots \\
& \text { Icsdc }_{\text {it }}=\alpha_{0}+\beta_{1} \text { Iliqd }_{\text {it }}+\beta_{2} \text { indt }_{\text {it }}+\beta_{3} \text { lleve }_{\text {it }}+\beta_{4} \text { Itaxa }_{\text {it }}+\beta_{5} \text { Ifsize }_{\text {it }}+\beta_{6} \text { Ifage }_{\text {it }}+\beta_{7} \text { Iccon }_{t}+ \\
& \beta_{8}\left(\text { indt }_{i t} \times \text { Iccon }_{\mathrm{t}}\right)+\lambda_{\mathrm{i}}+\varepsilon_{\mathrm{it}} \cdots \\
& \text { Icsdc }_{\text {it }}=\alpha_{0}+\beta_{1} \text { lliqd }_{\text {it }}+\beta_{2} \text { indt }_{\text {it }}+\beta_{3} \text { lleve }_{\text {it }}+\beta_{4} \text { Itaxa }_{\text {it }}+\beta_{5} \text { Ifsize }_{\text {it }}+\beta_{6} \text { Ifage }_{\text {it }}+\beta_{7} \text { Iccon }_{t}+ \\
& \beta_{8}\left(\text { lleve }_{i t} \times \text { Iccon }_{t}\right)+\lambda_{i}+\varepsilon_{i t} \cdots \\
& \text { Icsdc }_{\text {it }}=\alpha_{0}+\beta_{1} \text { lliqd }_{\text {it }}+\beta_{2} \text { indt }_{\text {it }}+\beta_{3} \text { lleve }_{\text {it }}+\beta_{4} \text { Itaxa }_{\text {it }}+\beta_{5} \text { Ifsize }_{\text {it }}+\beta_{6} \text { Ifage }_{\text {it }}+\beta_{7} \text { Iccon }_{t}+ \\
& \beta_{8}\left(\text { Itaxa }_{i t} \times \text { Iccon }_{t}\right)+\lambda_{i}+\varepsilon_{i t} \ldots
\end{aligned}
$$

The current study estimated regression models based on static panel regression. However, to solve the possible issue of endogeneity, a further test for robustness of the model under dynamic panel regression was conducted, where additional models G1 to G5 shall contained the lagged dependent variable ( $\mathbf{L l c s d c}_{\mathrm{t}-1}$ ) amongst the regressor. The dynamic panel regression is based on the generalised method of moments (GMM) using the two step, system GMM estimator (Blundell \& Bond, 1998). Additional dynamic GMM panel models were provided;

\subsection{Variable Measurement}

The study contained four categories of variables, namely; the dependent, independent, moderating and control variables. All variables, with the exception of a dummy variable represented by (indt), were expressed in natural logarithm of the datasets to express the dataset in a form that is proximate to a normal distribution, (Kamarudin, Sufian, \& Md. Nassir, 2016; Law \& Azman-Saini, 2012).

Firstly, the dependent variable in this study is the corporate sustainability disclosure (Icsdc) index. The index was developed using a set of data collected from the 118 sampled listed companies, The purpose of developing the index was to measure the extent to which companies complied with the nine (9) points of sustainability disclosure requirements, as contained in the Nigerian corporate governance code (SEC, 2011). The current study utilises the distinctively, total unweighted disclosure index, which was developed by Cooke (1989), using a binary scoring point which takes the value of 1 , if an item is disclosed by a firm in a particular year, or 0 if not disclosed (Joshi, Ling, Yin, \& Deshmukh, 2016; Sarhan \& Ntim, 2018).

Second set of variables are the independent variables which are measured as follows. Variable lliqd (liquidity) measured as proportion of cash to total asset and expressed in Naira (\#). indt (industry type) is a dummy that takes on the value 1 for firms in eight main industries: basic materials; oil and gas; industrial; customer goods; customer services; health care; technology and telecommunication and 0 for all other industries. lleve (leverage) is computed as the ratio of book value of total debt to total assets, expressed in percentage (\%). And lastly, Itaxa (taxation) is measured base on the total amount of corporate tax liability for the year, expressed in Naira ( $\$$ ).

Thirdly, corruption control index (Iccon), expressed as natural logarithm is considered to be the moderating variable in the study. Finally, two additional variables were used as control variables in the study, namely firm size (Ifsize) expressed in Naira ( $\mathbf{A}$ ), and the numeric variable for years since incorporation, or firm age (Ifage). The control variables were selected as these variables are often reported, and considered as significant and positive variables, when linked to corporate sustainability disclosure compliance (CSDC) variables, as evidenced from prior studies (Akhtaruddin, Hossain, Hossain, \& Yaho, 2009; Garas \& ElMassah, 2018; Gutierrez, Hlaciuc, Mates, \& Maciuca, 2016; Joshi et al., 2016; Lama \& Anderson, 2015; Wachira, 2017).

\subsection{Descriptive Statistics}

The descriptive statistics, shown in table 2 below, shows the data set were collected from 118 firms. The mean value of corporate sustainability disclosure compliance (csdc) was 66.49, with a standard 
deviation from the mean of 19.034. Liquidity (liqd) varied between -3.130 and 1342.029 with a mean of 19.347. Industry type (indt) showed 0 and 1 as minimum and maximum value, respectively, with a mean of 0.297. Leverage (leve) ranged between 0.179 and 5448.298 , with a standard deviation of 313.416. Taxation (taxa) fell between -37569.3 and 85342 , with a mean value of 1647.233 , and a standard deviation of 6147.607. Corruption control (ccon) fell between 24.6 and 29.4, with a mean of 27.114 and standard deviation of 1.615. Firm size (fsize) ranged between 98 and 6800000, with a mean of 275012.5. Finally, firm age (fage) fell between 1 and 94 , with a mean value of 34.380, and standard deviation of 19.331 .

Table 2: Descriptive Statistics

\begin{tabular}{|c|c|c|c|c|c|}
\hline Variable & Obs. & Mean & Std. Dev. & Min & Max \\
\hline csdc & 826 & 66.493 & 19.034 & 0 & 100 \\
\hline liqd & 826 & 19.347 & 67.783 & -3.130 & 1342.029 \\
\hline indt & 826 & 0.297 & 0.457 & 0 & 1 \\
\hline leve & 826 & 100.771 & 313.416 & 0.179 & 5448.298 \\
\hline taxa & 826 & 1647.233 & 6147.607 & -37569.3 & 85342 \\
\hline ccon & 1 (Nigeria) & 27.114 & 1.615 & 24.6 & 29.4 \\
\hline fsize & 826 & 275012.5 & 810666.5 & 98 & 6800000 \\
\hline fage & 826 & 34.380 & 19.331 & 1 & 94 \\
\hline
\end{tabular}

\section{Results and Findings}

\subsection{Diagnostic Checks}

Based on the test for multicollinearity, model S1 shows no evidence of a multicollinearity problem (vif $<5$ ). Contrastingly, the result for model S2 addionally shows a very strong correlation between liquidity (Iliqd), and the interacting variable (liqd*ccon). Thus, based on an initial vif of 749.65 , variable liquidity was dropped from the model, which resulted in a final vif result of 1.94 , as presented in table 3. An initial result from model S3 reveal a vif of 763.80 , with very strong correlation between industry and the interaction variable (indt*ccon). Subsequent elimination of industry type in the model led to a variance inflation factor of 1.94 . Similarly, the correlation coefficients for model S4 and S5, showed a very strong correlation of leverage and taxation with the interaction variables respectively. Thus, a new estimate was completed, after dropping the aforementioned variables revealed a favorable variance inflation factor of 1.94 for both models, as presented in table 3 .

Table 3: Diagnostic test for the moderating effect of corruption control models

\begin{tabular}{|c|c|c|c|c|c|c|}
\hline \multirow[b]{2}{*}{ Diagnostic } & \multirow[b]{2}{*}{ Test } & Model S1 & Model S2 & Model S3 & Model S4 & Model S5 \\
\hline & & $\begin{array}{c}\text { No } \\
\text { interaction }\end{array}$ & Iliqd`Iccon & indt ${ }^{\star} \mid c c o n$ & lleve*Iccon & Itaxa*Iccon \\
\hline \multirow[t]{2}{*}{ Multicollinearity } & Vif 1 (mean) & 1.98 & 749.65 & 763.80 & 740.84 & 757.12 \\
\hline & Vif 2 (mean) & - & 1.94 & 1.94 & 1.94 & 1.94 \\
\hline Serial correlation & $\begin{array}{c}\text { Wooldridge } \\
\text { test }\end{array}$ & $\begin{array}{c}\text { Prob }>F= \\
0.8064\end{array}$ & $\begin{array}{c}\text { Prob }>F= \\
0.8050\end{array}$ & $\begin{array}{c}\text { Prob }>F= \\
0.8293\end{array}$ & $\begin{array}{c}\text { Prob }>F= \\
0.8072\end{array}$ & $\begin{array}{c}\text { Prob }>F= \\
0.8067\end{array}$ \\
\hline Heteroscedasticity & $\begin{array}{l}\text { Modified } \\
\text { Wald }\end{array}$ & $\begin{array}{l}\text { Prob>chi2 } \\
=0.0000\end{array}$ & $\begin{array}{l}\text { Prob>chi2 } \\
=0.0000\end{array}$ & $\begin{array}{l}\text { Prob>chi2 } \\
=0.0000\end{array}$ & $\begin{array}{c}\text { Prob }>\text { chi } 2= \\
0.0000\end{array}$ & $\begin{array}{c}\text { Prob }>\text { chi } 2= \\
0.0000\end{array}$ \\
\hline
\end{tabular}

The result of the Wooldridge test for autocorrelation in panel shows no evidence for autocorrelation in models S1 to S5, testing the moderating role of corruption control. Wald test for group wise heteroscedasticity was applied to verify that the residuals in model S1 to S5 were not correlated with the explanatory variables, and provide evidence for heteroscedasticity in all models $(p<0.05)$ based on the result (refer to table 3$)$. Robust standard errors were used in all models to 
correct the problem. Using Cook's distance test for outliers, a set of outliers were system detected, and excluded from the list. Lastly, a total of 801 observations were considered in the static models with exception of model S2 with 802 observations as shown in table 4 below.

\subsection{Static Regression Results for the Moderating Effect of Corruption Control}

Models, S1 to S5 of Table 4 seek to determine the moderating effect of corruption control of the relationship of firm attributes with CSDC in Nigeria. Interpretation of the results for model S1 to S5 was based on random effect (RE) model estimation, as indicated by Hausman test $(p>0.05)$. At the initial stage of the analysis with model S1, the direct relationship of all the explanations, control and moderating variables on CSDC was tested, Subsequently, four (4) interaction variables (Iliqd*Iccon, indt*Iccon, Ileve*Iccon and Itaxa*Iccon) were tested using a stepwise regression approach.

It is crucially important to note that model S1 (refer to table 4), shows a relationship between the moderating variable (Iccon) and CSDC before any interaction is positive. However, this factor is not significant in any of the models (see model S1 to S5). Furthermore, the first interaction variable in model S2, between liquidity and corruption control (Iliqd*Iccon), reveals a positive relationship, but is not significant. This result indicates that the level at which the current fight against corruption strengthens the link of firm attributes on CSDC, is an insignificant effect in Nigeria.

Moreover, model S3 shows a positive and significant interaction between industry type and corruption control at the $1 \%$ level, as shown in table 4 . This implies that concurrent focus to improve the level of compliance in environmentally sensitive companies, and in the fight against corruption will have significant impact on the level of CSDC in Nigeria, with. This finding indicates that, with the moderating effect (indt*Iccon) expressed in model S4, the relationship between the corruption control and industry type appears to be significant. The finding is further supported by the neo-institutional theory which states that rules and regulations vary depending on the sector in which companies operate. However, the extent of compliance to any rules depend heavily on the level of trust in the authorities (Lin, Cheng, \& Zhang, 2017). This further supports the findings of that firms operating in various consumer products disclosure more sustainability related information (Sarhan \& Ntim, 2018; Wachira, 2017).

Similarly, the interaction variable presented in model $\$ 4$ depicts a link between leverage and control of corruption (Ileve*Iccon), as presented in table 4. The Chi square distribution result (68.23) for model fit is significant at $1 \%$ level, which indicates that the model is statistically appropriate to explain any variation in the CSDC level. Furthermore, based on the random effect (RE), the interaction variable is statistically significant at $1 \%$ level. Similar findings have been documented by Garas \& EIMassah (2018), Kachouri \& Jarboui (2017) and Lin et al. (2017). This result implies that where emphasis is given to increase in sources of debt for companies, and increase in attention to the fight against corruption, this will invariably strengthen the influence firm attributes on corporate sustainability disclosure compliance (CSDC) in Nigeria.

The final interaction (Itaxa*Iccon) as presented in model S5 in table 4. The moderating role of corruption control (Iccon) shows a direct positive, but insignificant relationship with CSDC. However, the interaction of taxation and corruption control reveal significant relationships with CSDC. However, negative effects of taxation, on CSDC, were observed in models S1 to S4, and also on the interaction variable in model S5, which indicates that the lower the corporate tax burden of companies in Nigeria, the higher the requirement level for corporate compliance to sustainability disclosure. Moreover, findings on the interaction effects of corruption control, with both leverage and taxation, were in line with the neo-institutionalism posit that weak institutions will facilitate weak compliance to rules (Acemoglu et al., 2003). Hence, considering the weak level of corruption control in Nigeria, increase in the level of access to finance, and reduction of tax burden shall strengthen the level of compliance with corporate sustainability disclosure regulatory guidelines. 
Table 4: Static Regression Results for the Moderating Effect of Corruption Control

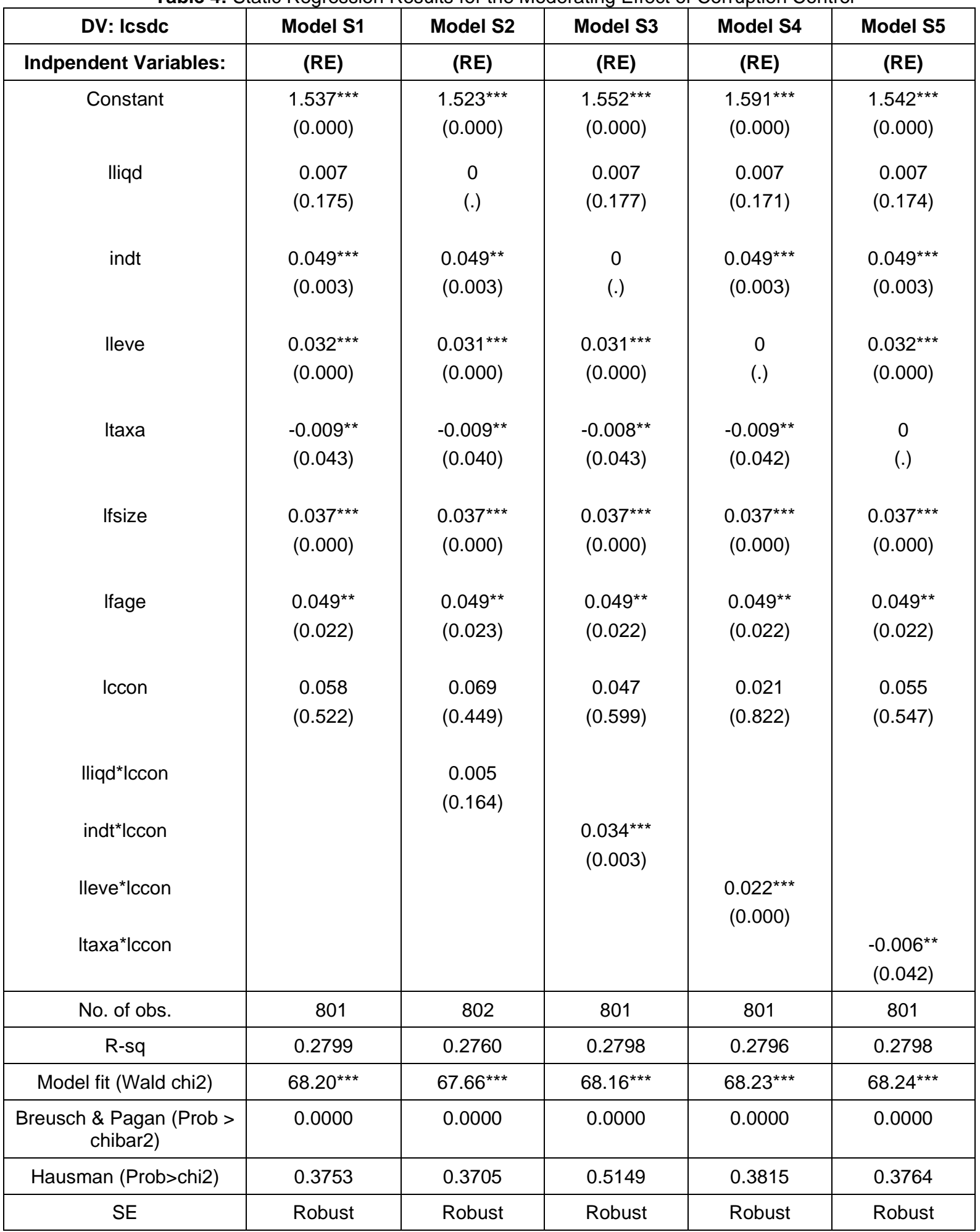

RE: Random Effect

p-values in parentheses: ${ }^{*} p<0.10,{ }^{* *} p<0.05,{ }^{* * *} p<0.01$

Corruption is a phenomenon capable of frustrating national planning, distorts political leadership, and poses a danger of transfer to subsequent generations (UN, 2017a). Corruption control in both public and private sectors is capable of leading the country to sustainable growth, and improved compliance of private companies to CSDC. Generally, based on the above findings from static regression analysis, there is sufficient evidence for the moderating effects of corruption control on the link between firm attributes and CSDC. Generally, the findings on the influence of corruption control on the corporate disclosures are supported by prior studies (Branco \& Matos, 2016; Healy \& Serafeim, 
2015; Issa \& Alleyne, 2018; Krasniqi \& Mustafa, 2016) that have documented a range of evidence, supporting the strong role of corruption control within the context of corporate operation and disclosure.

\subsection{Robustness Checks: Generalised Method of Moments (GMM)}

Based on the test for multicollinearity, the vif result for models G2 to S5 additional shows a very strong correlation (vif $>5$ ) between some explanatory variables with interaction variables. Thus, such explanatory variables (Iliqd, indt, lleve and Itaxa) were respectively dropped from each model, which resulted in a final vif result of 1.88 in each of the models, as presented in table 5 . The Cook's distance test was conducted whereby a total 682 observations were used for model G1, and 680 observations for model G2 to G5 were considered. The test of serial correlation for the results for AR1 showed a significant $p$-value for models $G 1$ to G5. Thus, the null hypothesis is rejected, for no first order serial correlation. Conversely, AR2 showed an insignificant p-value for all models G1 to G5, and signified that the null hypothesis is not rejected, in the second-order serial correlation, which is consistent with GMM estimation requirements. Finally, the moment conditions (instruments) in GMM estimations increase in direct proportion with time $(\mathrm{T})$, thus using the Sargan or Hensen test. All dynamic GMM models showed a p-value greater than 0.05 in both the Sargan and Hensen tests (see table 5). Therefore, based on the GMM conditions, we conclude that the instruments are valid and unbiased.

\subsection{GMM Regression Results for the Moderating Effect of Corruption Control}

The findings of the robustness check under dynamic GMM panel regression analysis are considered as the main regression result have satisfied all conditions necessary under the GMM estimation, as shown in table 5, as represented in models $G 1$ to G5. Model G1 tests the direct relationship of all explanatory. The explanatory variables in the model are statistically fit to explain the level of CSDC, as supported by evidence of the significant P-value of the Wald Chi square distribution results (refer to table 5). Model G1 results revealed a negative insignificant relationship between corruption control (Iccon) and the dependent variable (Icsdc). Similar findings were reported under the static panel. Moreover, variables such as lleve, Ifsize and Ifage indicated positive significance.

The first interaction variable between liquidity and corruption control (Iliqd*Iccon), in model G2, revealed a positive but not a significant relationship. However, consistent with the static regression is results of model G3, which indicated that at $1 \%$ level of significance, the interaction between industry type and corruption control shows a positive relationship with the dependent variable (Icsdc). Similarly, with respect to the interaction variable depicting a link between leverage and control of corruption (leve*ccon) in model G4, the result presented showed the interaction variable to be statistically significant at the $1 \%$ level. Specifically, four (4) variables; liquidity (lliqd), taxation (Itaxa), board independence (Ibindp) and the moderating variable (Iccon), appeared to be statistically significant in the current model G4. Furthermore, variables indt and Ifage shows slight increase in the coefficients. The last interaction (Itaxa*Iccon) in model G5, is shown in table 5. It is Important to note that the direct relationship for neither taxation nor corruption control appear to have a direct significant influence on the dependent variable. Moreover, the result indicates the insignificant negative relationship of the interaction between the interaction variables. 
Table 5: GMM Results for the moderating effect of Corruption Control

\begin{tabular}{|c|c|c|c|c|c|}
\hline DV: Icsdc & Model G2 & Model G3 & & Model G5 & Model G6 \\
\hline $\begin{array}{l}\text { Indpendent } \\
\text { Variables: }\end{array}$ & (GMM) & (GMM) & (GMM) & (GMM) & (GMM) \\
\hline \multirow[t]{2}{*}{ Constant } & $1.338^{* * *}$ & $1.353^{* * *}$ & $1.421^{\star \star *}$ & $1.453^{\star * *}$ & $1.419^{\star \star \star}$ \\
\hline & $(0.000)$ & $(0.000)$ & $(0.000)$ & $(0.000)$ & $(0.000)$ \\
\hline \multirow[t]{2}{*}{ L.Icsdc } & $0.182^{* * *}$ & $0.170^{\star * *}$ & $0.162^{\star \star \star}$ & $0.173^{* * *}$ & $0.167^{\star \star \star}$ \\
\hline & $(0.007)$ & $(0.007)$ & $(0.009)$ & $(0.005)$ & $(0.006)$ \\
\hline \multirow[t]{2}{*}{ Iliqd } & 0.014 & 0 & 0.016 & 0.013 & 0.015 \\
\hline & $(0.215)$ & (.) & $(0.153)$ & $(0.245)$ & $(0.130)$ \\
\hline \multirow[t]{2}{*}{ indt } & $0.036^{* *}$ & $0.036^{* *}$ & 0 & $0.041^{* *}$ & $0.042^{* *}$ \\
\hline & $(0.049)$ & $(0.040)$ & (.) & $(0.026)$ & $(0.028)$ \\
\hline \multirow[t]{3}{*}{ lleve } & $0.032^{* *}$ & $0.038^{* * *}$ & $0.045^{\star \star \star}$ & 0 & $0.040^{\star * \star}$ \\
\hline & $(0.016)$ & $(0.004)$ & $(0.001)$ & (.) & $(0.001)$ \\
\hline & -0.001 & -0.001 & -0.007 & -0.000 & 0 \\
\hline \multicolumn{6}{|l|}{ Itaxa } \\
\hline & $(0.948)$ & $(0.910)$ & $(0.654)$ & $(0.960)$ & (.) \\
\hline \multirow[t]{2}{*}{ Ifsize } & $0.026^{* *}$ & $0.027^{* *}$ & $0.029^{\star}$ & $0.026^{*}$ & $0.029^{*}$ \\
\hline & $(0.047)$ & $(0.044)$ & $(0.072)$ & $(0.057)$ & $(0.075)$ \\
\hline \multirow[t]{2}{*}{ Ifage } & $0.041^{*}$ & $0.046^{\star *}$ & $0.052^{\star *}$ & $0.049^{* *}$ & $0.049^{* *}$ \\
\hline & $(0.084)$ & $(0.043)$ & $(0.031)$ & $(0.029)$ & $(0.027)$ \\
\hline \multirow[t]{2}{*}{ Iccon } & -0.003 & -0.014 & -0.072 & -0.092 & -0.069 \\
\hline & $(0.970)$ & $(0.874)$ & $(0.437)$ & $(0.286)$ & $(0.467)$ \\
\hline \multirow[t]{2}{*}{ Iliqd*Iccon } & & 0.009 & & & \\
\hline & & $(0.271)$ & & & \\
\hline \multirow[t]{2}{*}{ indt*|ccon } & & & $0.030^{* *}$ & & \\
\hline & & & $(0.024)$ & & \\
\hline \multirow[t]{2}{*}{ lleve*Iccon } & & & & $0.027^{* * *}$ & \\
\hline & & & & $(0.003)$ & \\
\hline \multirow[t]{2}{*}{ Itaxa*Iccon } & & & & & -0.005 \\
\hline & & & & & $(0.623)$ \\
\hline
\end{tabular}




\begin{tabular}{|c|c|c|c|c|c|}
\hline $\mathrm{N}$ & 682 & 680 & 680 & 680 & 680 \\
\hline Instruments & 39 & 38 & 53 & 55 & 55 \\
\hline Vif 1 (mean) & 1.88 & 594.10 & 591.85 & 586.15 & 596.70 \\
\hline Vif 2 (mean) & - & 1.88 & 1.88 & 1.88 & 1.88 \\
\hline Wald $\mathrm{Chi}^{2}$ & $93.01^{* * *}$ & $100.82^{\star * *}$ & $101.58^{* * *}$ & $93.28^{* * *}$ & $94.55^{\star \star \star}$ \\
\hline $\mathrm{AR}(1)$ & 0.000 & 0.000 & 0.000 & 0.000 & 0.000 \\
\hline $\operatorname{AR}(2)$ & 0.480 & 0.419 & 0.324 & 0.429 & 0.361 \\
\hline Sargan & 0.585 & 0.716 & 0.000 & 0.677 & 0.666 \\
\hline Hensen & 0.403 & 0.417 & 0.575 & 0.615 & 0.605 \\
\hline
\end{tabular}

\section{Conclusion}

Corruption is considered a threat to sustainable development. The issue is of critical concern to authorities in Nigeria. The country is currently intensifying the fight against corruption with special emphasis on its public sector. Thus, this study investigated the moderating effects of corruption control on the relationship of firm attributes on corporate sustainability disclosure compliance. Furthermore, the empirical findings were interpreted based on neo-institutional theory. Subsequently, three interaction variables relating corruption control with industry type, leverage, and taxation were examined, and findings from stepwise regression under the static model reported, that showed support for the hypothesis of the moderating role of corruption control. Moreover, similar findings were reported under the dynamic GMM panel regression analysis. However, interaction between liquidity and corruption control appeared not to be statistically significant.

Moreover, our findings provided significant theoretical and empirical insight in support of future studies. The fact that, the findings shall further provide a deeper understanding on the interrelationship between various structures within the formal institutional environment, and how actions within the larger institutions through corruption control shall influence corporate behaviour in the area of corporate sustainability disclosure compliance. We recommend that, regulators and policy makers must enact policies targeted toward intensifying the fight against corruption in Nigeria. The study has considered these efforts as critical to a sustainable private sector in the country, and that it is crucial to increase the level of compliance with corporate sustainability disclosure.

The main limitation of this study is that, the findings are based on Nigerian context. As such, the result cannot be generalised to other developing countries. Secondly, the analysis is based on quantitative methodological choice. However, future studies may focus on other developing economies with the aim of exploring factors that influence the extent of corporate sustainability disclosure compliance using qualitative or mixed methodological approaches.

\section{Declaration of Ownership}

This work is our original work

\section{Conflict of Interests}

None 


\section{References}

1. Acemoglu, D., Johnson, S., Robinson, J., \& Thaicharoen, Y. (2003). Institutional causes, macroeconomic symptoms: volatility, crises and growth. Journal of Monetary Economics, 50, 49123.

2. Adelopo, I. (2011). Voluntary disclosure practices amongst listed companies in Nigeria. Advances in Accounting, Incorporating Advances in International Accounting, 27(2), 338-345. https://doi.org/10.1016/j.adiac.2011.08.009

3. AKhtaruddin, M., Hossain, M. A., Hossain, M., \& Yaho, L. (2009). Corporate governance and voluntary disclosure in corporate annual reports of Malaysian listed firms. Journal of Applied Management Accounting Research, 7(1), 1-20.

4. Atwood, T. J., Drake, M. S., Myers, J. N., \& Myers, L. A. (2012). Home country tax system characteristics and corporate tax avoidance: International evidence. The Accounting Review, 87(6), 1831-1860.

5. Branco, M. C., \& Matos, D. (2016). The fight against corruption in Portugal : evidence from sustainability reports. 23(1), 132-142. https://doi.org/10.1108/JFC-05-2014-0027

6. Business Anti-Corruption Portal BAP. (2018). Nigeria Corruption Report. Retrieved November 19, 2017, from GAN Integrity Inc. website: https://www.business-anti-corruption.com/countryprofiles/nigeria/

7. Campbell, J. L. (2007). Why would corporations behave in socially responsible ways? An institutional theory of corporate social responsibility. Academy of Management Review, 32(3), 948-967.

8. Cooke, T. E. (1989). Disclosure in the corporate annual reports of Swedish companies. Research, Accounting and Business, 19(74), 113-124.

9. DiMaggio, P., \& Powell, W. (1983). The iron cage revisited: institutional isomorphism and collective rationality in organizational fields. American Sociological Review, 48(2), 147-160.

10.Eltaib, E. E., \& Complete, A. (2012). Environmental accounting disclosures of Australian oil and gas companies. University of Wollongong.

11.Garas, S., \& EIMassah, S. (2018). Corporate governance and corporate social responsibility disclosures. Critical Perspectives on International Business, 14(2-26), cpoib-10-2016-0042. https://doi.org/10.1108/cpoib-10-2016-0042

12.Gutierrez, H. P., Hlaciuc, E., Mates, D., \& Maciuca, G. (2016). Empirical study of financial disclosure compliance with IFRS: Evidence from listed Romanian companies. Journal of Accounting and Auditing: Research \& Practice, 2016(July), 11. https://doi.org/10.5171/2016.794159

13. Healy, P. M., \& Serafeim, G. (2015). An analysis of firms' self-reported anticorruption efforts. The Accounting Review, 91(2), 489-511.

14.latridis, G. E. (2013). Environmental disclosure quality : Evidence on environmental performance, corporate governance and value relevance. Emerging Markets Review, 14, 55-75. https://doi.org/10.1016/j.ememar.2012.11.003

15.Issa, A., \& Alleyne, A. (2018). Corporate disclosure on anti-corruption practice. Journal of Financial Crime, 25(4), 1077-1093. https://doi.org/10.1108/JFC-05-2017-0045

16.Joseph, C., Gunawan, J., Sawani, Y., Rahmat, M., Noyem, J. A., \& Darus, F. (2016). A comparative study of anti-corruption practice disclosure among Malaysian and Indonesian corporate social responsibility (CSR) best practice companies. Journal of Cleaner Production, 112, 2896-2906.

17.Joshi, P. L., Ling, L. C., Yin, L. W., \& Deshmukh, A. (2016). Disclosure choices, corporate characteristics and compliance with IFRS practice statement management commentary: An empirical study of Malaysian listed companies. Global Business and Economics Review, 18(6), 679703. https://doi.org/10.1504/GBER.2016.079411

18.Kachouri, M., \& Jarboui, A. (2017). Exploring the relation between corporate reporting and corporate governance effectiveness. https://doi.org/10.1108/JFRA-06-2016-0053 
19.Kamarudin, F., Sufian, F., \& Annuar Md. Nassir. (2016). Does country governance foster revenue efficiency of Islamic and conventional banks in GCC countries? EuroMed Journal of Business, 11(2), 181-211.

20.Krasniqi, B. A., \& Mustafa, M. (2016). Small firm growth in a post-conflict environment: the role of human capital, institutional quality, and managerial capacities. International Entrepreneurship and Management Journal, 12(4), 1165-1207. https://doi.org/10.1007/s11365-016-0384-9

21.Krejcie, R. V., \& Morgan, D. W. (1970). Determining sample size for research activities. Educational and Psychological Measurement, 30(3), 607-610. https://doi.org/https://doi.org/10.1177/001316447003000308

22.Lama, T., \& Anderson, W. W. (2015). Company characteristics and compliance with ASX corporate governance principles. Pacific Accounting Review, 27(3), 373-392. Retrieved from http://scihub.cc/10.1108/par-12-2013-0104\%0A

23.Lasagni, A., Nifo, A., \& Vecchione, G. (2015). Firm productivity and institutional quality: Evidence from italian industry. Journal of Regional Science, 55(5), 774-800. https://doi.org/10.1111/jors.12203

24.Law, S. H., \& Azman-Saini, W. N. W. (2012). Institutional quality, governance, and financial development. Economics of Governance, 13(3), 217-236. https://doi.org/10.1007/s10101-0120112-z

25.Lin, K. Z., Cheng, S., \& Zhang, F. (2017). Corporate Social Responsibility, Institutional Environments, and Tax Avoidance: Evidence from a Subnational Comparison in China. International Journal of Accounting, 52(4), 303-318. https://doi.org/10.1016/j.intacc.2017.11.002

26.Onyali, C. I., Okafor, G. T., \& Egolum, P. (2014). An Assessment of environmental information disclosure practices of selected Nigerian manufacturing companies. International Journal of Finance and Accounting, 3(6), 349-355. https://doi.org/10.5923/j.ijfa.20140306.03

27.Powell, W. W. (1988). Institutional effects on organizational structure and performance. Institutional Patterns AndOrganizations: Culture and Environment, 115-136.

28.Qureshi, M. I., Khan, N., Qayyum, S., Malik, S., Sanil, H. S., \& Ramayah, T. (2020). Classifications of sustainable manufacturing practices in ASEAN region: A systematic review and bibliometric analysis of the past decade of research. Sustainability, 12(21), 8950.

29.Said, R. M., Sulaiman, M., \& Ahmad, N. N. N. (2014). Environmental information usefulness to stakeholders: empirical evidence from Malaysia. Social Responsibility Journal, 10(2), 348-363. https://doi.org/10.1108/SRJ-10-2012-0131

30.Salihu, H. A., \& Gholami, H. (2019). Corruption in the Nigeria Judicial System : An Overview. Journal of Financial Crime, 25(3), 669-680. https://doi.org/10.1108/JFC-01-2017-0005

31.Sarhan, A. A., \& Ntim, C. G. (2018). Firm- and country-level antecedents of corporate governance compliance and disclosure in MENA countries. Managerial Auditing Journal, 33(6-7), 558-585. https://doi.org/10.1108/MAJ-10-2017-1688

32.SEC. (2011). Code of Corporate Governance For Public Companies in Nigeria. Code, pp. 1-60. Retrieved from http://sec.gov.ng/regulation/rules-codes/\%0A

33.SEC. (2018). Listed Cimpanies in Nigeria. Retrieved April 3, 2018, from http://www.nse.com.ng/Listings-site/listed-securities/listed-companies

34.Sekaran, U. (2003). Research methods for business a skill building approach (4th ed.). USA: John Wiley \& Sons Inc.

35.Shan, S., Lin, Z., Li, Y., \& Zeng, Y. (2018). Attracting Chinese FDI in Africa: The role of natural resources, market size and institutional quality. Critical Perspectives on International Business, 14(2-3), 139-153. https://doi.org/10.1108/cpoib-11-2016-0055

36.Trading Economics. (2020). Nigeria corruption rank. Retrieved from https://tradingeconomics.com/nigeria/corruption-rank

37.Tresierra, A. E., \& Reyes, S. D. (2018). Effects of institutional quality and the development of the banking system on corporate debt. Journal of Economics, Finance and Administrative Science, 23(44), 113-124. https://doi.org/10.1108/JEFAS-03-2017-0053 
38.UN. (2017a). Corruption in Nigeria Bribery: public experience and response. Retrieved from https://www.unodc.org/documents/data-and-analysis/Crimestatistics/Nigeria/Corruption_Nigeria_2017_07_31_web.pdf

39.UN. (2017b). The emissions gap report 2017. Retrieved April 9, 2017, from https://wedocs.unep.org/bitstream/handle/20.500.11822/22070/EGR_2017.pdf

40.Wachira, M. (2017). Determinants of Corporate Social Disclosures in Kenya : A Longitudinal Study of Firms Listed on the Nairobi Securities Exchange. European Scientific Journal, 13(11), 112-132. https://doi.org/10.19044/esj.2017.v13n11p112

World Bank. (2018). Combating corruption. Retrieved November 20, 2018, from http://www.worldbank.org/en/topic/governance/brief/anti-corruption 